\title{
LXVII. On the connexion between the Boetian and the middle-Arabic numerical forms
}

\author{
J.O. Halliwell Esq. F.R.S. F.S.A.
}

To cite this article: J.O. Halliwell Esq. F.R.S. F.S.A. (1839) LXVII. On the connexion between the Boetian and the middle-Arabic numerical forms, Philosophical Magazine Series 3, 15:98, 447-449, DOI: $10.1080 / 14786443908649920$

To link to this article: http://dx.doi.org/10.1080/14786443908649920

册 Published online: 01 Jun 2009.

Submit your article to this journal $[\pi$

Џ Article views: 2

Q View related articles $\square$ 
well as of siliceous sandstones and slates, which I refer to an upper group of the Devonian rocks, and of these I have prepared sections and details for the Dublin Geological Society.

The lower figure in the accompanying plate will, it is hoped, sufficiently explain my views of the order of succession.

Dublin, October $93,1839$.

LXVII. On the Connexion between the Boetian and the MiddleArabic mumerical Forms. By J. O. HaLliweln, Esq., F.R.S., F.S.A., \& . $^{*}$

$\mathrm{N}$ the Comptes Rendus des Séances de l'Acalcémie des Sciences for the 7th of October, M. Libri and M. Chasles have commented at some length on certain portions of an essay on the Boetian numerical contractions which I ventured to place before the notice of the public some months ago. I hasten to explain some opinions there given, which I regret have been found to be expressed in too ambiguous terms to give sufficient satisfaction to the inquiries of those zealous and learned mathematicians.

With respect to the Bodleian manuscripts, I believe I have erred in asserting that in all three treatises local position is clcarly pointed out, for in the tract of Berhelinus this is only to be inferred ; but whatever doubt may arise in that case, I am fully persuaded that in the first Hattonian manuscript (No. 7), and in the treatise immediately preceding that of Berhelinus in the second Hattonian MS. (No. 112), not only is local position clearly pointed out, but there is quite as complete a system of Arithmetic as we find in the treatises of Johannes de Sacro-Bosco, or Alexander de Villa Dei. For, after all, the arithmetic of those authors is nothing more than the simplest adaptation of abacal principles, and every one knows that in contemnorary MSS. of those treatises, snd even in transcripts of as recent a peried as the close of the 15 th century, all the marginal operative examples are given in the abacal form, and only one step removed from the Arundel manuscript, where a blank space is used instead of the sipos. Again, even in the Arundel manuscript, which does not possess one higher principle than the passage in Boetius, although local position is not clearly pointed out, yet, as I have elsewhere stated, the woriter roas evidently acquainted with the decuple value which a digit receives by its siluation on the left of anothert.

* Communicated by the Author.

$\uparrow$ Appendix to a Life of Sir Samuel Morland, p. 26. 


\section{$448 \mathrm{Mr}$. Halliwell on the Boetian and Arabic Numerals.}

The names alone are almost sufficient to show that the origin of these numerals is Eastern, if not from the Arabic; but it appears to me that sufficient attention has not been paid to the variations of the forms of the figures in different manuscripts. Now, in the tract de ratione abaci, we have invariably two lists of forms, and these again vary in MSS. of different ages. Let us make a brief comparison of a few of them.

1. In all the manuscripts to which $I$ have referred, igin is the same, and agrees with the common middle-Arabic form.

2. Andras does not vary to any extent, but how easily is it convertible to the Arabic form !

3. Ornus in MS. Lansd. 842, is the same with ornus in MS. Arund. 34.3 transversed, and this is an example of a curious result of practice, the truth of which $I$ hope to be able to establish universally. In MS. Harl. 3595, of the tenth century, we find two forms of ornus very nearly identical with the Arabic.

4. The form of arbas is not so readily convertible to the Arabic, but a bisection of this character in its second place in MS. Harl. 3595, and in MS. Lansd. 842, would make the loop of the middle-Arabic figure.

5. Quinas, as given in MS. Arund. 343, is identical with the middle-Arabic form. In MS. Harl. 3595, and in many other early manuscripts, this character is transversed.

6. Chalcus is evidently convertible to the common form by the mere obtainable effect of convenient expression.

7. Zenis, as given in the MS. Arundel. 343, rahen transversed, is identical with the middle-Arabic form. Examples of it, in that state, may be seen in MS. Lansd. 84.2, and MS. Harl. 3595 .

8. Zemenias agrees in form with the common character.

9. Celentis agrees, by transversion, with the common form. The second form of this figure in MS. Lansd. 842 is transversed.

I am almost inclined to believe from these examples, and from others equally conclusive which can be brought forward, that, in the case of middle numerals, transversion is invariably true in the change of form they underwent, provided that any reasonable theory is thereby supported. Perhaps also we may arrive at an additional argument from the Eastern manner of writing from the right to the left ; for what is more probable than, supposing the case of a Latin scribe copying the numerals from the Arabic, that he should turn them upside down, for the facility thus afforded by that means of copying them in the proper order? Thus would the transversion be satisfactorily accounted for, and without a conjecture so vio- 
Mr. Halliwell on the Boetian and Arabic Numerals. $\quad 149$

lently improbable as to induce one to reject it on the grounds of no immediate evidence*.

Boetius immediately precedes the passage de ratione abaci by definitions of numbers, digiti, arliculi, and compositi,-a division which, I may observe, could only have been subservient to the use of the Abacus, and the very same which Alexander de Villa Dei and others, expressly using the Arabic calculus, have employed in their works $t$. This is a strong argument; and in MS. Trin. Coll. Cantab. R. xv. 16, we find the Boetian digital forms identical with the middle-Arabic with the exception of a very slight deviation in ornus, and having arbas written on one side.

I venture to exhibit the following conclusions, which I hope will not be considered too premature.

1. That the Boetian contractions are wholly independent of the middle-Arabic in their introduction into Europe.

2. 'That the Boetian contractions formed a distinct system of decimal numeration, borrowed from the East, and introduced through the Latins into Eastern Europe.

3. That the Boetian notation was anterior to the introduction of the middle-Arabic numerals through Spain.

Professor Davies, in a key to the new edition of Hutton's Course of Mathematics, now on the eve of publication, has given some entirely new views relative to the period of change between the abacal and concentrated modes of operation, and it is on that account that I defer entering into that part of the subject, because his arguments are so forcible, so conclusive, and agree so well with an examination of early manuscripts, that an abridgement would sensibly deteriorate their value; moreover, as the work itself will ere long be so accessible to every one, there can be no necessity.

I hope shortly to be able to put in a form fit for publication some researches on the Leopoldine Numerical Contrnctions, which form a system of numeration that has hitherto entirely escaped the researches of every writer on the history of arithmetic. Thus within the space of a few months will a completely new face be laid on the history of the Hindoo arithmetic in Europe during the middle ages.

* I entered into a full explanation of the results of this conjecture in a paper read before the Royal Society of Literature, but which is not yet printed.

+ Rara Mathematica, p. 2, 74; Professor Peacock's History of Arithmetic, in Encyc. Metrop.

Phil. Mag. S. 3. Vol. 15. No. 98. Dec. 1839. 